\title{
MODERNE KOLOVOZNE KONSTRUKCIJE NA ŠUMSKIM KAMIONSKIM PUTEVIMA
}

\section{Modern carriageway construction on forest truck roads}

\author{
Senad Kozar ${ }^{1}$, Dževada Sokolović ${ }^{2}$, Muhamed Bajrić
}

\begin{abstract}
Construction of forest roads which was at low professional level long time ago, now days are going in pace with modern trends so it became more and more complex along with more requirements. Appearance of vehicles higher traffic load and necessity for as fast as possible transport of large quantity of timber caused the constructing resistant of carriageway. Construction of modern carriageway on forest roads in $\mathrm{BiH}$ is very actual issue, because current status of forest roads does not meet needs of forestry as the economy branch.

The cost of construction of upper layer of the road with modern carriageway accounts for $60-70 \%$ of the cost of whole road construction, and it is necessary to make comprehensive economic analysis.

In this paper the review of development of traffic ways on forest roads has been presented and comparison of economic and technical features between unpared carriageway and asphalt carriageway has been made.
\end{abstract}

Key words: forest roads, traffic load, capacity carriageway construction, the costs of construcion carriageway.

\section{Izvod}

Gradnja šumskih puteva koja je u dalekoj prošlosti bila na niskom stručnom nivou, danas u savremenim uslovima ide u korak sa modernim htijenjima, pa je postala sve složenija i zahtjevnija.

Pojava vozila većeg saobraćajnog opterećenja, kao i potreba za što bržim transportom velikih količina drvne mase, uslovili su gradnju otpornijih kolovoznih konstrukcija.

Gradnja savremenog kolovoza na šumskim putevima u BiH veoma je aktuelno pitanje, jer postojeće stanje ne zadovoljava potrebe šumarstva kao privredne grane.

\footnotetext{
1 d.o.o "Šuming" - Travnik

2 Šumarski fakultet Univerziteta u Sarajevu - Faculty of Forestry University of Sarajevo
} 
Cijena gradnje gornjeg stroja puta sa savremenim kolovozom participira sa $60-70 \%$ u ukupnim troškovima njegove gradnje, te stoga zahtijeva prethodnu detaljnu ekonomsku analizu.

U radu je dat pregled razvoja kolovoznih konstrukcija na šumskim putevima. Na konkretnim šumskim putevima izvršeno je poređenje ekonomskih i tehničkih karakteristika za kolovoz od makadama i asfaltnu kolovoznu konstrukciju.

Ključne riječi: šumski putevi, saobraćajno opterećenje, nosivost kolovozne konstrukcije, troškovi gradnje.

\section{Uvod - Introduction}

U dalekoj prošlosti Rimljani su bili poznati po gradnji puteva. Izgradili su oko 150000 kilometara putne mreže. Mnogi od ovih puteva bili su sagrađeni od kamenih ploča debljine oko 90 centimetara, pa se ostaci ovih puteva i danas mogu naći. Nakon ovog perioda nastaje stagnacija u razvoju gradnje puteva sve do osamnaestog vijeka, kada je francuski inženjer Trezage unaprijedio postupak građenja, tako što je preko podloge od krupnog kamena stavljao sitniji kamen. U isto vrijeme u Engleskoj Telford i Mac Adam (po njemu se zove makadamski kolovoz) razvijaju sličan tip kolovozne konstrukcije. Tako Telford na podlozi među krupnije kamenje utiskuje sitnije frakcije, dok McAdam koristi drobljeni kamen u više slojeva sa obaveznim zbijanjem. Počeci razvoja savremenih kolovoznih konstrukcija vezani su za otkrivanje portland cementa 1875. godine (CVETANOVIĆ, 1992).

Kolovozne konstrukcije na šumskim putevima u $\mathrm{BiH}$ se prema postojećim smjernicama za projektovanje šumskih kamionskih puteva dimenzioniraju za maksimalno opterećenje $10 \mathrm{t}$ ili $100 \mathrm{kN}$ po osovini. Razlog za ovakve dimenzije kolovoza jesu kamioni, koji se za prevoz drvnih sortimenata kod nas počinju intenzivno koristiti od druge polovine šezdesetih godina. Tipični predstavnik kamiona iz ovog perioda jeste kamion FAP 13 B koji ima nosivost 8 t. Nakon ovih kamiona u upotrebu dolaze i kamioni FAP 16 - 20, te MAGIRUSI 310 D i kamioni tipa TAM (ovi kamioni su u u svom sastavu imali i hidrauličnu dizalicu tipa HIAB ili LIV). Nosivost ovih kamiona bila je oko 13 tona. Daljim razvojem saobraćajne tehnike, osamdesetih godina, počinje i primjena tzv. kompozicija koje su u svom sastavu imale kamion FAP 18 sa dizalicom i poluprikolicom.

Uz gore pomenute kamione, danas se za prevoz šumskih sortimenata koriste kamioni velike nosivosti raznih proizvođača: VOLVO, SCANIA, MERCEDES, MAN, RENAULT itd. Ukupna nosivost savremenih kamiona je do 50 tona. Na slici 1 je data šema sa osovinskim opterećenjem novijih tipskih vozila.

Kako su postojeće kolovozne konstrukcije na šumskim putevima projektovane za manja osovinska opterećenja, veoma brzo dolazi do njihovog propadanja. Stoga su potrebna značajna finansijska sredstva za njihovo održavanje . 
S obzirom da moderne kolovozne konstrukcije ispunjavaju zahtjeve u pogledu nosivosti savremenih kamiona, logično se postavlja pitanje opravdanosti gradnje modernih kolovoznih konstrukcija na šumskim putevima.

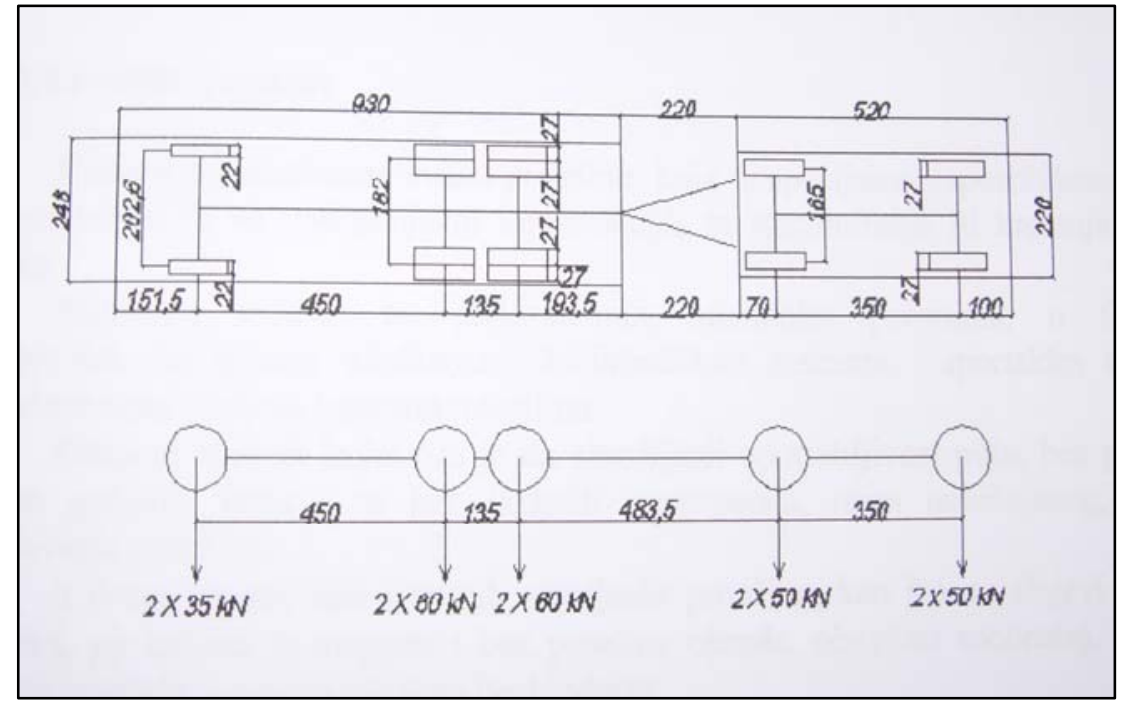

Slika 1. Šema novijih tipskih vozila: kamion sa prikolicom $31+20 \mathrm{t}$

Figure 1 Newer schemes typical of vehicles: Truck with trailer $31+20 t$

\subsection{Vrste kolovoza na šumskim putevima - Types of carriageway on forest roads}

Kolovozni zastor je završni sloj kolovozne konstrukcije koji sile izazvane dejstvom vozila (vertikalne, tangencijalno uzdužne i tangencijalno poprečne) prima i prenosi na niže slojeve kolovoza (donji stroj). Osim sila izazvanih dejstvom vozila, kolovozni zastor mora biti otporan i na klimatske i hidrološke promjene, jer je direktno izložen uticaju ovih faktora.

JELIČıć (1983) prema vrsti materijala od kojeg je izgrađen kolovoz daje slijedeću podjelu šumskih puteva :

- zemljani putevi,

- putevi sa kamenim kolovozom,

- putevi sa savremenim kolovozom i

- razne kamene kaldrme.

Zemljani putevi su izgrađeni bez kolovoznog zastora od postojećeg zemljišta na terenu gdje se put gradi. Kvalitet zemljanih puteva se poboljšava ukoliko se uradi stabilizacija prirodnog zemljišta nekom od poznatih metoda: prirodna stabilizacija, mehanička i hemijska stabilizacija.

Kameni kolovozi s obzirom na debljinu kolovozne konstrukcije mogu biti slijedećih sistema: 
- Tucanički kolovoz sistema Mac Adam - Sastoji se iz više slojeva debljine 10 $-70 \mathrm{~cm}$ u uvaljanom stanju. Debljina kolovoza zavisi od nosivosti tla; što je nosivost tla manja debljina kolovoza je veća. Izrada ovakvog kolovoza sastoji se iz tri faze.

- Tucanički kolovoz sistema Telford ili šose - Sastoji se iz kamene podloge nosivog sloja debljine $15-20 \mathrm{~cm}$ i gornjeg sloja (zastora) debljine $8-15 \mathrm{~cm}$. Ovakva vrsta kolovoza se do 1965. godine primjenjivala na svim šumskim putevima jer se smatralo da podloga od lomljenog kamena ima funkciju temelja i spriječava formiranje kliznih površina.

- Šljunčani kolovoz - Sastoji se iz dva sloja šljunčanog materijala $10-70 \mathrm{~cm}$ debljine u uvaljanom stanju. Oko $80 \%$ šljunčanog materijala ima veličinu zrna 10 / $60 \mathrm{~mm}$, a $20 \%$ su veličine ispod $10 \mathrm{~mm}$.

Savremeni kolovozi se grade pomoću raznih vrsta veziva koja daju čvrstoću kamenom agregatu u površinskom ili habajućem sloju. Ovisno o vrsti veziva, savremeni kolovozi se dijele na dvije vrste: asfaltni i betonski. $\mathrm{Na}$ osnovu veziva kojim je obavijen ili vezan kameni materijal u zastoru dijele se na :

- kolovozne zastore sa ugljovodoničnim vezivom,

- kolovozne zastore sa hidrauličkim vezivom i

- savremene kamene kolovoze.

Prema saobraćajnom opterećenju, šumski putevi se dijele na:

- puteve za srednje težak saobraćaj sa saobraćajnim opterećenjem od 500 do 2500 bruto tona/dan,

- puteve za laki saobraćaj sa saobraćajnim opterećenjem ispod 500 bruto tona /dan (100-500) i

- puteve za neznatan (vrlo lak saobraćaj) sa saobraćajnim opterećenjem ispod 100 bruto tona/dan

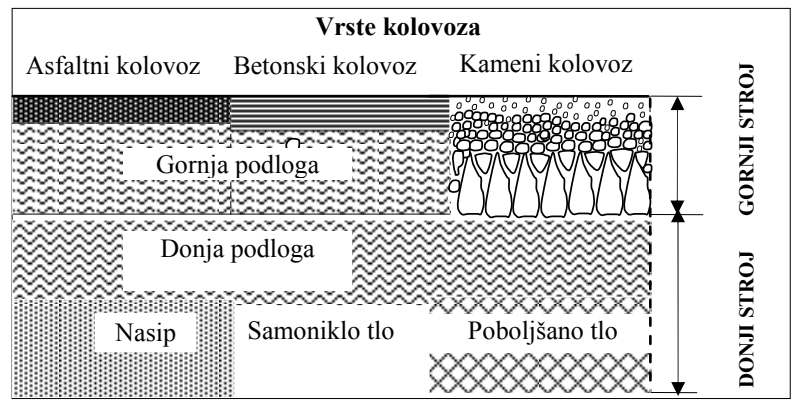

Slika 2. Šematski prikaz osnovnih elemenata različitih vrsta kolovoznih konstrukcija, PIČMAN (2007) Figure 2 Schemes review of basic elements of different types of structures carriageway, PIČMAN (2007.) 
$\mathrm{Na}$ slici 2 je dat šematski prikaz osnovnih elemenata različitih vrsta kolovoznih konstrukcija.

Najbitniji uticajni faktori za izbor vrste kolovoza su: saobraćajno opterećenje, nosivost posteljice, uticaj okoline i uticaj deformacije tla, PIČMAN (2007).

Problem izbora vrste kolovoza je složen i komplikovan, a naročito u slučajevima kada su uticajni faktori mnogobrojni i različiti, ponekad čak u suprotnosti.

Zbog toga je potrebno dobro poznavanje značaja pojedinih uticaja kod rješavanja svakog slučaja.

Kvalitet i nosivost tla su, pored saobraćajnog opterećenja, najznačajniji faktori kako za debljinu kolovozne konstrukcije tako i vrstu kolovoznog zastora. Kad je tlo dovoljne i ravnomjerne nosivosti, mogućnosti za izbor vrste kolovoza su znatno šire. Za manje nosiva tla dobro rješenje je cementno betonski kolovoz jer ravnomjernije prenosi opterećenje na tlo. Asfaltni i kameni kolovozi sa tucaničkom podlogom su elastični i pogodni za tla neravnomjerne nosivosti (nasipe nejednake ili nedovoljne zbijenosti i sl.).

Izbor kolovoznog zastora u velikoj mjeri određuje saobraćajno opterećenje. Potrebno je poznavati trajnost u godinama (n) pojedinih kolovoznih zastora pod raznim saobraćajnim opterećenjem, kao i godišnje troškove za njihovo održavanje.

\subsection{Održavanje puteva - Road maintenance}

Održavanje se može definisati kao skup operacija koje je potrebno povremeno obavljati na putevima, pratećim objektima (bankine, kanali, kosine) i na vještačkim objektima (mostovi, potporni zidovi, propusti itd.) u cilju nesmetanog odvijanja saobraćaja. Generalno može se reći da što se više uloži vremena, stručnosti i novca u planiranje i gradnju šumskih puteva manje sredstava će biti potrebno za održavanje.

Tri su glavne grupe uzroka degradacije šumskih puteva (РОтоČNIK, 1992):

- posljedica planiranja i izgradnje šumskih puteva,

- posljedica neodgovarajućeg korištenja šumskih puteva i

- posljedica prirodnih sila.

Prema PIČMANU (2007) s obzirom na učestalost pojedinih vrsta radova, tj. vremensko razdoblje u kojem se ti radovi izvode, postoje dvije osnovne grupe održavanja:

- redovno održavanje,

- investiciono održavanje.

Redovno održavanje se sastoji u stalnom nadzoru i kontroli radi utvrđivanja eventualnih nedostataka i oštećenja na putu. U redovno održavanje spada i čišćenje jaraka, kolovoza od blata i nanosa, održavanje kosina usjeka i nasipa, bankina, čišćenje snijega i spriječavanje poledice.

Investiciono održavanje se sastoji u obnovi kolovoza na površinama gdje udarne rupe pokrivaju $15 \%$ ukupne površine kolovoza, ili na površinama na kojima je došlo do deformisanja ili propadanja kolovozne konstrukcije. U investiciono 
održavanje spada jačanje kolovozne konstrukcije izradom novog sloja, zamjena oštećenih drenaža, sanacija klizišta, oštećenih potpornih zidova i opravke mostova.

\section{Područje istraživanja - Area research}

Za područje istraživanja izabrana su dva lokaliteta na ŠPP „Lašvansko“ i to dva glavna šumska kamionska puta:

1. Šumski kamionski put „Busovača - Pridolci - Luke“, dužine 6220 m koji se nalazi u GJ „Busovača“. Ovaj put otvara odjele 111 do 165 koji imaju 1929,20 ha sa godišnjom sječivom drvnom masom $19620 \mathrm{~m}^{3}$. U upotrebi je tokom cijele godine, a na dijelu puta $u$ dužini od $300 \mathrm{~m}$ urađena je modernizacija kolovoznog zastora, tipa asfalt beton.

2. Šumski kamionski put „Babanovac“, odjel 97, dužine $7531 \mathrm{~m}$ koji se nalazi u GJ „Gornji Ugar“. Ovaj put otvara odjele 91 do 125 koji imaju ukupnu površinu 1368,52 ha i godišnju sječivu drvnu masu $17000 \mathrm{~m}^{3}$. Nastao je prevođenjem šumske željeznice $u$ šumski kamionski put. Zbog Sportskorekreacionog centra „Babanovac“ 2004. godine modernizovan je kolovozni zastor na dužini od $300 \mathrm{~m}$.

\section{Materijal i metode - Material and methods}

Ispitivanja su vršena na osnovu uzetih uzoraka na stacionažama koje su izabrane metodom slučajnog uzorka. Na izabranim stacionarnim tačkama uzeta su po tri uzorka, i to u tri različita godišnja doba u vremenskom intervalu od oko jedne godine. Datumi uzimanja uzoraka su: 12.05.2004. godine, 10.11.2004. godine i 02.06.2005. godine.

Ispitivanja su vršena kružnom pločom površine $70000 \mathrm{~mm}^{2}$. Ispitivani su slijedeći parametri:

- debljina kolovoza,

- modul stišljivosti (Ms),

- granulometrijski sastav i stepen neravnomjernosti.

Metoda ispitivanja pločom koristi se pri ocjeni nosivosti slojeva kolovozne konstrukcije izgrađenih od nestabilizovanih materijala. Veličina modula deformacije modula stišljivosti (Ms) ili modula deformabilnosti (Ev2), zavisi od stepena zbijenosti ispitivanog materijala. Priroda tog odnosa funkcija zavisi od slijedećih faktora:

- stepena plastičnosti materijala,

- vlažnosti materijala u toku ispitivanja,

- plastičnosti finozrnih frakcija u praškastim i glinovitim vrstama šljunka,

- Hazenovog koeficijenta neravnomjernosti za pojedine vrste pijeska i šljunka kontinualnog granulometrijskog sastava bez finozrnih plastičnih frakcija. 
Maksimalne veličine modula stišljivosti (Ms) postižu se na materijalima određenog stepena zbijenosti, samo ako je njihova vlažnost u momentu ispitivanja bliska optimalnoj ili neznatno manja od optimalne. Značajan je uticaj granulometrijskog sastava i oblika zrna na veličinu modula stišljivosti (Ms), budući da je materijal riječni šljunak sa zaobljenim zrnima, a drobljeni materijal oštrih ivica.

Asfalt-betonski kolovoz BNS 22 na području istraživanja analiziran je prema standardnoj MARSHALL-ovoj metodi. Ova metoda se koristi za ispitivanje stabilnosti, krutosti i vodonepropusnosti asfaltnih mješavina u cilju određivanja potrebne količine bitumena. Za ispitivanje se priprema pet serija uzoraka od iste kamene mješavine, ali sa različitim procentima veziva, od kojih su dvije serije sa količinama manjim od procijenjene optimalne (najčešće se procenat veziva povećava za po $0,5 \%$ mase u odnosu na prethodnu). Na osnovu rezultata ispitivanja pojedinih svojstava, dobijenih direktno ili računski, crtaju se odgovarajući dijagrami i prema njima određuje optimalna količina bitumena asfaltne mješavine. Potrebna količina bitumena određuje se kao srednja vrijednost količine bitumena dobijenih iz četiri dijagrama. Ako na taj način određena količina bitumena ne obezbjeđuje potrebna fizičko-mehanička i reološka svojstva asfaltne mješavine, potrebno je da se obave odgovarajuće korekture granulometrijskog sastava kamene mješavine ili da se promijeni vrsta bitumena.

\section{Rezultati - Results \\ 4.1. Troškovi gradnje kolovoza - Costs of construction carriageway}

\subsubsection{Troškovi gradnje kolovoza na šumskom kamionskom putu „Babanovac“, odjel 97 - Costs of construction carriageway on forest truck roads "Babanovac", Department 97}

Urađena je detaljna kalkulacija troškova gradnje šumskog kamionskog puta „Babanovac“, odjel 97, dužine 7,531 km. Kalkulacija je urađena po pojedinim fazama rada prema cjenovniku koji se koristio za te radove na području ŠPP „Lašvansko“ $u$ periodu 2003. i 2004. godine. Rekapitulacija troškova predmjera i predračuna radova za šumski kamionski put „Babanovac“, odjel 97, dužine 7,531 km sa makadamskim zastorom, prikazana je u tabeli 1 , a rekapitulacija troškova za isti put urađen sa asfaltnim zastorom data je u tabeli 2 .

Uporednom analizom predmjera i predračuna radova za šumski kamionski put "Babanovac" odjel 97, dužine 7,531 km sa zastorom od makadama, i predmjera i predračuna radova za isti put sa zastorom od asfalta, može se vidjeti da su pripremni radovi za oba zastora ostali isti i iznose $17.339,80 \mathrm{KM}$. Isti troškovi su i za izradu donjeg stroja puta i iznose 299.623,40 KM. Takođe, troškovi gradnje objekata na ovom putu su za obje vrste zastora isti i iznose 24.282,70 KM. Međutim, troškovi gradnje gornjeg stroja puta za varijantu sa makadamskim zastorom iznose 114.639,00 $\mathrm{KM}$, dok je na istom putu za asfaltni kolovoz potrebno 357.056,10 KM. Dakle, ukupni troškovi gradnje kolovoza od asfalta su viši za 32,11 \%. 
Tabela 1. Rekapitulacija troškova za šumski kamionski put „Babanovac“, odjel 97, dužine $7,531 \mathrm{~km}$ sa makadamskim zastorom

Table 1 The costs of forest truck road "Babanovac", Department 97, length of $7531 \mathrm{~km}$ with macadam curtain

\begin{tabular}{|l|r|}
\hline I - PRIPREMNI RADOVI & $17.339,80 \mathrm{KM}$ \\
\hline II - DONJI STROJ & $299.623,40 \mathrm{KM}$ \\
\hline III - OBJEKTI & $24.282,70 \mathrm{KM}$ \\
\hline IV - GORNJI STROJ I OPREMA & $114.639,00 \mathrm{KM}$ \\
\hline UKUPNO: & $455.944,90 \mathrm{KM}$ \\
\hline Po $1 \mathrm{~km}:$ & $60.542,40 \mathrm{KM}$ \\
\hline
\end{tabular}

Tabela 2. Rekapitulacija troškova za šumski kamionski put „Babanovac“, odjel 97, dužine $7,531 \mathrm{~km}$ sa asfaltnim zastorom

Table 2 The costs of forest truck road "Babanovac", Department 97 ,length of 7,531 km with asphalt curtain

\begin{tabular}{|l|r|}
\hline I - PRIPREMNI RADOVI & $17.339,80 \mathrm{KM}$ \\
\hline II - DONJI STROJ & $299.623,40 \mathrm{KM}$ \\
\hline III - OBJEKTI & $24.282,70 \mathrm{KM}$ \\
\hline IV - GORNJI STROJ I OPREMA & $357.056,10 \mathrm{KM}$ \\
\hline UKUPNO: & $698.302,00 \mathrm{KM}$ \\
\hline Po $1 \mathrm{~km}:$ & $92.723,70 \mathrm{KM}$ \\
\hline
\end{tabular}

\subsubsection{Troškovi gradnje kolovoza na šumskom kamionskom putu „Busovača - Luke“ dužine $6,220 \mathrm{~km}$ - Costs of construction carriageway forest truck roads "Busovaca - Luke" the length of $6220 \mathrm{~km}$}

Kao i za šumski put „Babanovac“, odjel 97, urađena je detaljna kalkulacija predmjera i predračuna radova za šumski kamionski put „Busovača - Luke“, dužine $6,220 \mathrm{~km}$. U tabeli 3 prikazana je rekapitulacija troškova gradnje analiziranog puta za kolovoz sa makadamskim zastorom, a u tabeli 4 data je rekapitulacija troškova gradnje za kolovoz sa asfaltnim zastorom.

Na šumskom kamionskom putu „Busovača - Luke“, dužine 6,220 km troškovi za pripremne radove iznose 15.399,90 KM i isti su za obje vrste kolovoza. Troškovi gradnje donjeg stroja i objekata na ovom šumskom kamionskom putu za obje vrste kolovoznih konstrukcija takođe su iste..

Međutim, troškovi gradnje gornjeg stroja za makadamski kolovoz iznose 115.128,00 KM, dok je za asfaltni kolovoz potrebno 336.155,70 KM.

Poređenjem ukupnih cijena koštanja po km' puta, iz tabela 1 i 2 . uočljivo je da put sa asfaltim zastorom ima veće troškove za $34,25 \%$. 
Tabela 3. Rekapitulacija troškova za šumski kamionski put „Busovača - Luke“, dužine 6,220 kmsa makadamskim zastorom (prebaciti u gornji red)

Table 3 The costs of forest truck road "Busovaca - Luke" the length of $6220 \mathrm{~km}$ with macadam curtain

\begin{tabular}{|l|r|}
\hline I - PRIPREMNI RADOVI & $15.399,90 \mathrm{KM}$ \\
\hline II - DONJI STROJ & $234.147,20 \mathrm{KM}$ \\
\hline III - OBJEKTI & $18.433,40 \mathrm{KM}$ \\
\hline IV - GORNJI STROJ I OPREMA & $115.128,00 \mathrm{KM}$ \\
\hline UKUPNO: & $383.108,50 \mathrm{KM}$ \\
\hline Po $1 \mathrm{~km}:$ & $61.593,00 \mathrm{KM}$ \\
\hline
\end{tabular}

Tabela 4. Rekapitulacija troškova za šumski kamionski put „Busovača - Luke“, dužine 6,220 $\mathrm{km}$ sa asfaltnim zastorom (prebaciti u gornji red)

Table 4 The costs of forest truck road "Busovaca - Luke" the length of $6220 \mathrm{~km}$ with asphalt curtain

\begin{tabular}{|l|r|}
\hline I - PRIPREMNI RADOVI & $15.399,90 \mathrm{KM}$ \\
\hline II - DONJI STROJ & $234.147,20 \mathrm{KM}$ \\
\hline III - OBJEKTI & $18.433,40 \mathrm{KM}$ \\
\hline IV - GORNJI STROJ I OPREMA & $326.653,20 \mathrm{KM}$ \\
\hline UKUPNO: & $594.633,70 \mathrm{KM}$ \\
\hline Po $1 \mathrm{~km}:$ & $95.600,30 \mathrm{KM}$ \\
\hline
\end{tabular}

\subsection{Analiza nosivosti kolovoza - Analysis of bearing capacity of carriageway}

\subsubsection{Analiza nosivosti puta sa zastorom od makadama - Analysis of capacity roads with makadam carriageway curtain}

Uzorci za analizu na oba analizirana šumska kamionska puta uzeti su u tri navrata na slijedećim stacionažama: $1+100,2 ; 2+150$ i $5+950$.

Datumi uzimanja uzoraka su: 12.05.2004. godine, 10.11.2004. godine i 02 . 06.2005. godine.

Rezultati provedene analize uzetih uzoraka su slijedeći:

a) Uzorci uzeti 12.05.2004. godine imaju debljinu tamponskog sloja 10 i 11 cm (nalaz br. 1,2,3 - za šumski put „Busovača - Luke“; 4,5 i 6 - za šumski put „Babanovac“, odjel 97). Zahtjevani modul stišljivosti za uzete uzorke se kreće od $103,45 \mathrm{MPa}$ do $115,38 \mathrm{MPa}$. Upoređivanjem rezultata analize sa referentnim vrijednostima koji iznose za modul stišljivosti minimalno $80 \mathrm{~N} / \mathrm{mm}^{2}$, a za debljinu zaštitnog sloja $10 \mathrm{~cm}$, može se zaključiti da su u dozvoljenim granicama i za nosivost i za debljinu zaštitnog sloja.

Napomena: U prilogu je dat nalaz br. 1 kao primjer. 
b) Uzorci uzeti 10.11.2004. godine (nalaz br. 7,8,9 za šumski put „Busovača Luke“; 10,11 i 12 za šumski put „Babanovac“, odjel 97) imaju debljinu tamponskog sloja od 7 do $10 \mathrm{~cm}$. Modul stišljivosti se kreće u intervalu od 81,08 MPa do 96,77 MPa i u granicama je dozvoljenog.

c) Uzorci uzeti 02.06.2005. godine (nalaz br. 13,14,15 za šumski put „Busovača - Luke“; 16,17 i 18 za šumski put „Babanovac“, odjel 97) karakterišu se debljinom tamponskog sloja 5 do $7 \mathrm{~cm}$. Modul stišljivosti uzetih uzoraka je u granicama od 63,83 MPa do 75,00 MPa i ispod je granica dozvoljenog.

Upoređivanjem rezultata analize uzoraka može se zaključiti da je debljina kolovoza od izmjerenih $11 \mathrm{~cm}$, koliko je zabilježeno kod prvog mjerenja, smanjena na 5 do $7 \mathrm{~cm}$, koliko je izmjereno u uzorcima koji su uzeti oko godinu dana poslije. Takođe modul stišljivosti koji je kod uzoraka uzetih 12.05.2004. godine bio u dozvoljenim granicama, u uzorcima uzetim 02.06.2005. godine je ispod dozvoljene granice.

Razlozi za ovako veliku promjenu ispitivanih elemenata makadamskog kolovoza su, između ostalog, i neuobičajeno velike sniježne padavine koje su zabilježene u analiziranom periodu. Čišćenjem snijega mjestimično je uklanjan zastor pa i dio tamponskog sloja sa puta, čime je smanjena debljina i nosivost kolovoza. Uz klimatske uticaje razlog za značajno smanjivanje debljine i nosivosti kolovoznog zastora jesu vozila sa velikim saobraćajnim opterećenjem koja se na ovom području gotovo isključivo koriste za transport drvne mase.

\subsubsection{Analiza stabilnosti puta sa asfaltnim kolovoznim zastorom - Analysis of capacity roads with asphalt carriageway curtain}

Analiza dijela puta sa asfaltnim kolovoznim zastorom obavljena je $u$ iste dane kao i analiza kolovoza sa makadamskim zastorom. Rezultati analize stabilnosti asfaltnog zastora sa analiziranog puta iznose 10,96 do 15,04 kN (nalaz br. $21 \mathrm{u}$ prilogu), a zahtjevana stabilnost za srednje saobraćajno opterećenje je minimalno 6 $\mathrm{kN}$. Ukočenost iznosi od 3,59 do $4,82 \mathrm{kN} / \mathrm{mm}$, a zahtjevana ukočenost je minimalno $2,2 \mathrm{kN} / \mathrm{mm}$. Dakle, najbitnije karakteristike na dijelu puta sa asfaltnim kolovoznim zastorom su i pored nepovoljnih vremenskih uticaja ostale u granicama dozvoljenog, pa će ovaj dio puta biti na raspolaganju za eksploataciju i u narednom periodu, bez značajnih finansijskih ulaganja. S druge strane, na dijelu puta sa makadamskim kolovoznim zastorom, pošto je došlo do velikog smanjenja debljine kolovoza i do značajnog smanjenja modula stišljivosti, bit će potrebna značajna finansijska sredstva za njegovu rekonstrukciju .

Sasvim logično postavlja se pitanje da li je na analiziranim šumskim putevima ekonomično ulaganje u rekonstrukciju makadamskog kolovoznog zastora. Odgovor je pozitivan jer je modernizacija opravdana, pogotovo kad se ima u vidu drvna masa koja gravitira ovim šumskim putevima, kao i mogući nepovoljni planinski klimatski uslovi koji utiču na brzo propadanje makadamskog kolovoznog zastora. 


\subsection{Mogućnost primjene savremenih kolovoznih konstrukcija na šumskim putevima - Possibility of applying modern carriageway structures on forest roads}

Iz analize predmjera i predračuna troškova gradnje kolovoznog zastora od makadama i asfaltnog kolovoznog zastora, došlo se do saznanja da:

- troškovi gradnje asfaltnog kolovoznog zastora su za oko 35 \% viši od troškova gradnje kolovoznog zastora od makadama,

- prilikom izbora kolovozne konstrukcije osim troškova gradnje treba uzeti u obzir i troškove održavanja.

načajne su prednosti asfaltnog kolovoznog zastora, a posebno:

- veća nosivost kolovoza, pa je omogućeno olakšano kretanje i vozilima sa velikim saobraćajnim opterećenjem,

- povećana brzina protoka saobraćaja,

- manji troškovi održavanja, jer se održavaju samo bankine i jarci, a kod makadama mora se održavati i zastor,

- prevozna sredstva koja učestvuju u kretanju po putu sa asfaltnim kolovozom imaju znatno duži vijek trajanja i manje se kvare.

Modernizacija kolovozne konstrukcije može se izvoditi etapno, dio po dio puta. Pri tome je značajna činjenica da svaka urađena etapa ne gubi na svojoj nosivosti ako se radi čak i o višegodišnjim etapama. To, prema rezultatima koji su dobijeni ovim istraživanjem, nije slučaj sa kolovozom od makadama, jer se nosivost i debljina slojeva ovakvog kolovoza smanjuje, ponekad i značajnije u nepovoljnim vremenskim uslovima i dešava se u veoma kratkom vremenskom periodu.

\section{Zaključci - Conclusions}

1. Najznačajniji faktor koji utiče na izbor i dimenzioniranje kolovozne konstrukcije na šumskim putevima jeste saobraćajno opterećenje. Prema postojećim smjernicama za projektovanje šumskih kamionskih puteva, kolovozna konstrukcija se dimenzionira za maksimalno opterećenje od $10 \mathrm{t}$ po osovini. Danas je na šumskim putevima $\mathrm{u} \mathrm{BiH}$ sve više vozila čija opterećenja prelaze $10 \mathrm{t}$ po osovini.

2. Uporednom analizom troškova gradnje šumskog kamionskog puta sa kolovoznom konstrukcijom od makadama i asfaltnom kolovoznom konstrukcijom došlo se do slijedećih rezultata :

- Troškovi pripreme, gradnje donjeg stroja i objekata za obje varijante su jednaki

- Razlika u troškovima gradnje je značajna kod predmjera i predračuna troškova gradnje gornjeg stroja odnosno kolovozne konstrukcije

- Na osnovu provedene analize koja je urađena za dva šumska kamionska puta: „Babanovac“, odjel 97, dužine 7,531 km i put „Busovača - Luke“, dužine $6,220 \mathrm{~km}$ može se zaključiti da su troškovi gradnje gornjeg stroja 
sa asfaltnim zastorom za oko $35 \%$ viši od troškova gradnje puta sa makadamskim kolovoznim zastorom.

3. Uporednom analizom nosivosti i stabilnosti kolovoznih konstrukcija sa makadamskim i asfaltnim zastorom, koja je provedena terenskim i laboratorijskim ispitivanjem uzoraka, može se zaključiti da su najznačajnije karakteristike makadamskog kolovoznog zastora, a to su debljina kolovoza i modul stišljivosti, $u$ vremenskom intervalu od oko jedne godine, koliko je trajalo ispitivanje, došle ispod minimalne granice koja se zahtijeva za ovakve kolovozne zastore. S druge strane, ispitivanjima provedenim na asfaltnom kolovoznom zastoru, $\mathrm{u}$ istom vremenskom periodu i na istim lokacijama, dobijeni su rezultati za stabilnost koji su u zahtjevanim granicama za ovu vrstu kolovoza.

\section{Literatura - Literature}

BAJRAMBAŠIĆ, I., 2000: Finansiranje i tehnička procedura projekata transporta Bosančica - Print Sarajevo

BENEŠ, J., 1974: Moderne metode izgradnje i održavanja gornjeg stroja šumskih puteva, Jugoslovenski poljoprivredno šumarski centar, Beograd

BUTULIJA, S., 1972: Kolovozi na šumskim putevima, Šumarski fakultet Sarajevo

CVETANOVIĆ, A., 1992: Kolovozne konstrukcije, Naučna knjiga, Beograd.

ĐUKIĆ, Ž., 1963: Građenje savremenih puteva u nekim zemljama Evrope, Građevinska knjiga, Beograd

FRĆO, M., 1984: Modernizacija kolovoznih konstrukcija šumskih cesta na području ŠG „Mojica Birta“ - Bjelovar, Jugoslovenski poljoprivredno šumarski centar, Beograd

IVKovIĆ, S., 1967: Ispitivanje stanja puteva sa zastorom od vodom vezanog makadama radi izrade projekta za njihovu sanaciju i rekonstrukciju - knjiga 2, Beograd

JELIČIĆ, V., 1976: Održavanje šumskih puteva, Privredna komora BiH, Sarajevo

Pičman, D., 2007: Šumske prometnice, sveučilišni udžbenik. Šumarski fakultet Sveučilišta u Zagrebu, str. 1-460.

Pотос̌NIK, I. (1992) Economical and technical aspects of forest road maintenance: master of science thesis. 129 pp, Biotechnical faculty, Ljubljana.

Privremeni tehnički propisi za projektovanje šumskih puteva u BiH, 1957.

ŽEFROA, Ž., 1975: Projektovanje i građenje kolovoznih konstrukcija, sveska 1, vozila, tlo i proračun konstrukcija, Građevinska knjiga, Beograd 


\section{Summary - Sažetak}

Building modern carriageway on forest roads in $\mathrm{BiH}$ is very topical question, because the current state of roads does not meet the needs of forestry as an economic sector. The appearance of the vehicle with the increasing traffic load on the forest roads in $\mathrm{BiH}$ as well as the need to include as quicker deliveries of wood to the place of processing, imposed the need for analysis of new application opportunities contemporary carriageway that will answer the aforementioned requirements. The paper is in two selected forest truck times executed comparison of economic and technical elements for two different types of structures carriageway: macadam and asphalt. On the basis of the analysis that was done in two forest truck times, "Babanovac - Department 97" length of 7531 kilometers, and time "Busovaca - Luke" the length of $6220 \mathrm{~km}$ can be concluded that the cost of construction of the above machine with asphalt curtain around for about 35\% higher than the cost of construction times with macadam carriageway. Comparative analysis of capacity carriageway structures with macadam and asphalt curtain can be concluded that the most important characteristics of macadam carriageway curtain in a time interval of about one year during the duration of testing, they came under the minimum limits of that application for such carriageway hangings. On the other hand, tests conducted on asphalt carriageway curtain, in the same period of time and at the same location, obtained the results hold up, who are demanding limits for this type of carriageway. 


\section{PRILOZI}

\section{Nalaz br. 1}

Kružna ploča $70000 \mathrm{~mm}^{2}$

\section{NALAZ}

o izvršenom opitu kružnom pločom

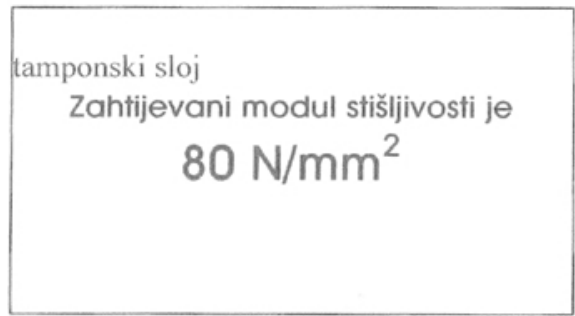

OBJEKAT: $\quad$ Sumski put Busovaca - Luke

PROFIL :

STACIONAŽA : $0+100$

POLOŽAJ U PROFILU

VRSTA SLOJA :

tamponski

VRSTA MATERIJALA :

drobljeni kameniti

VLAŽNOST :

prirodna

DEBLJINA SLOJA :

$10 \mathrm{~cm}$

DUBINA POD NIVELETOM:

TEMPERATURA :

VRIJEME :

suncano

\section{REZULTATI OPITA :}

opterećenje

$\left(\mathrm{N} / \mathrm{mm}^{2}\right)$

\begin{tabular}{|c|c|c|}
\hline 0,05 & & 0,08 \\
\hline 0,10 & & 0,26 \\
\hline 0,15 & & 0,39 \\
\hline 0.20 & & 0,54 \\
\hline 0,25 & & 0,68 \\
\hline 0,30 & & 0,79 \\
\hline 0,35 & & 0,94 \\
\hline 0,40 & & 1,03 \\
\hline 45 & & 1,11 \\
\hline$=$ & 0,29 & $\mathrm{~mm}$ \\
\hline & 0.10 & $\mathrm{~N} / \mathrm{mm}^{2}$ \\
\hline & 300 & $\mathrm{~mm}$ \\
\hline
\end{tabular}

slijeganje ( $\mathrm{mm}$ )

0,08

0,54

0,68

94

1,11
10

12

$M s=D^{*} \Delta p / \Delta s=$

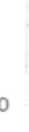


Nalaz br. 19

TAMPON ZA SUMSKI PUT BUSOVACA - LUKE

Laboratorijski rezultat
\begin{tabular}{|c|c|c|c|}
\hline \# sito & ostalo ( gr ) & ostalo ( \% ) & prošlo (\%) \\
\hline 63 & & & 100 \\
\hline 45 & & & 100,00 \\
\hline 31,5 & & & 95,40 \\
\hline 22,4 & & & 92,00 \\
\hline 16 & & & 81,25 \\
\hline 11,2 & & & 73,43 \\
\hline 8 & & & 66,70 \\
\hline 4 & & & 52,30 \\
\hline 2 & & & 38,40 \\
\hline 1 & & & 30,03 \\
\hline 0,71 & & & 25,60 \\
\hline 0,5 & & & 22,23 \\
\hline 0,25 & & & 17,43 \\
\hline 0,125 & & & 11,13 \\
\hline 0,09 & & & 8,52 \\
\hline 0,063 & & & 8,52 \\
\hline dno & & & 8,52 \\
\hline
\end{tabular}

Granulometrijski sastav tampona prema uslovima Knjige II

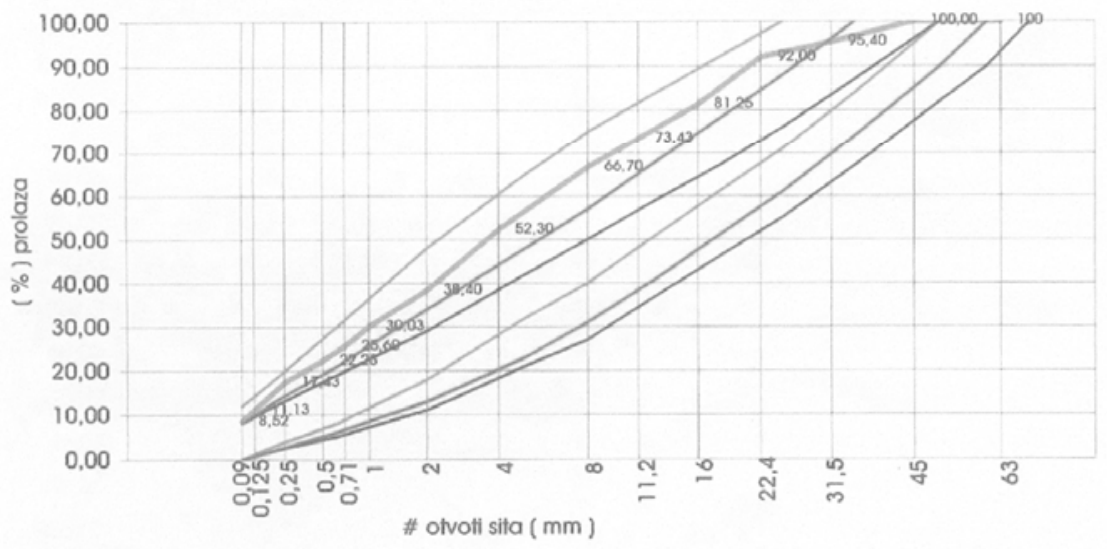

U1

tampon $0 / 35 \mathrm{~mm}$
$-\operatorname{tampon} 0 / 50 \mathrm{~mm}$ 
Nalaz br. 21

OBJEKAT: Sumski put Busovaca - Luke

NARUCILAC ISPITIVANJA :

BROJ I DATUM NARUDŻBE

PROIZVOĐAČ ASFALTNE MJEŠAVINE

IZVOEAC RADOVA :

VRSTA SLOJA : BNS 22 S

DATUM UGRADNJE ASFALTA: 20.06.2004.g.

MJESTO UZETOG UZORKA : sa trase puta

NALAZ br

o ispitivanju uzorka asfalta BNS 22

\begin{tabular}{|c|c|c|c|c|c|}
\hline \multirow{2}{*}{$\begin{array}{c}\text { ISPITIVANA SVOJSTVA } \\
\text { ( Standardna Marshall-ova metoda) }\end{array}$} & \multirow{2}{*}{$\begin{array}{l}\text { Rezultati } \\
\text { ispitivanja }\end{array}$} & \multicolumn{4}{|c|}{ Zahtjevano prema U.E9.021 za saobr. opt. } \\
\hline & & $\begin{array}{c}\text { AP i } \\
\text { vrlo teśko }\end{array}$ & teško & srednje & $\begin{array}{c}\text { lahko i } \\
\text { vrio lahko }\end{array}$ \\
\hline
\end{tabular}

\section{1) LABORATORIJSKI UZORAK ASFALTNE MJEŠAVINE}

\begin{tabular}{|c|c|c|c|c|}
\hline Stabilnost ( na $60^{\circ} \mathrm{C}$ ) & $\mathrm{kN}$ & 15,04 & $\min 6$ & $\min 3$ \\
\hline Tečenje ( na $60^{\circ} \mathrm{C}$ ) & $\mathrm{mm}$ & 3,12 & & \\
\hline Ukočenost ( na $60^{\circ} \mathrm{C}$ ) & $\mathrm{kN} / \mathrm{mm}$ & 4,82 & $\min 2,2$ & $\min 1,8$ \\
\hline Modul ukočenosti ( na $60^{\circ} \mathrm{C}$ ) & Mpa & 76,16 & & \\
\hline Maksimalna zapreminska težina & $\mathrm{kg} / \mathrm{m}^{3}$ & 2.580 & & \\
\hline Zapreminska težina lab. uzorka & $\mathrm{kg} / \mathrm{m}^{3}$ & 2.446 & & \\
\hline Śupljine u agregatu & $\%$ & 14,40 & & \\
\hline Šupljine u asfaltnoj mješavini & $\%$ & 5,19 & 4 do 9 & 3 do 9 \\
\hline Ispunjenost kamene smjese bitumenon & $\%$ & 63,97 & & \\
\hline
\end{tabular}

II) UZORAK IZ IZVEDENOG SLOJA

\begin{tabular}{|l|c|c|c|c|c|c|}
\hline Debljina sloja & $\mathrm{cm}$ & 5,22 & \multicolumn{4}{|c|}{} \\
\hline Zapreminska masa & $\mathrm{kg} / \mathrm{m}^{3}$ & 2.403 & & & 3 do 9 & 2 do 10 \\
\hline Udio Šupljina & $\%$ & 6,86 & & & 98 & 97 \\
\hline Stepen zbijenosti & $\%$ & 98,24 & & & 97 \\
\hline
\end{tabular}

III) BITUMEN U ASFALTNOJ MJEŠAVINI

\begin{tabular}{|l|l|r|r|}
\hline U ukupnoj asfaltnoj mješavini & $\%$ & 3,83 \\
\hline U odnosu na 100 dijelova agregata & $\%$ & 3,98 \\
\hline
\end{tabular}

